\title{
A Critical Review of Netra Sharir of Ayurveda in the Modern Perspective
}

\author{
Dr. Mula Ram Suthar ${ }^{1}$, Dr. Rakesh Roushan ${ }^{2 *}$
}

\author{
${ }^{1}$ M.D. Scholar, Kriya Sharir, CBPACS, New Delhi India \\ ${ }^{2}$ Assistant Professor, Kriya Sharir, CBPACS, New Delhi India
}

DOI: $10.36348 /$ sijtcm.2020.v03i03.002

| Received: 21.02.2020 | Accepted: 01.03.2020 | Published: 07.03.2020

*Corresponding author: Dr. Rakesh Roushan

\section{Abstract}

The Indian system of Ayurvedic medicine has described three basic physiological constituents of human body, viz., dosha, dhatu and mala. Acharya Sushruta was a great surgeon in ancient India known today as the "Father of Shalya Tantra (Surgery)" for inventing and developing surgical procedures. Acharya Sushruta has elaborately described the defining characteristic of Shalakya tantra. It comprises of the disease of shalakya tantra as narrated by king of Videha (the author of Nimi Tantra). Acharya Sushruta first ever has described the anatomy of eye in relation to their shape, size of various anatomical components. Acharya Sushruta has also described the Netra roga in a very systematic manner. In the Uttara tantram, Sushruta recites an elaborated classification of eye disease complete with signs, symptoms, prognosis and medically surgical interventions. In the foetus, the parts of eye are originated from akasha, vayu, agni, apa and prithvi mahabhuta. Acharya Sushruta has described all anatomical structures of the eye in terms of madala, patala, sandhis, peshi, marma, sira and Dristi. Susruta delineated fine anatomical divisions mandala of eye. Different Acharyas have their own view in the utpatti (origin) of Netra during garbhawastha kala. Increased demand of Ayurveda science in the present society is required to understand the depth of Ayurvedic principle in an easy mode. Hence an effort has been made to ascertain and establish the knowledge regarding anatomical structure of netra sharir.

Keywords: Ayurveda, Netra, Field of vision, Mandala, Patala, Sandhi.

Copyright @ 2020: This is an open-access article distributed under the terms of the Creative Commons Attribution license which permits unrestricted use, distribution, and reproduction in any medium for non-commercial use (NonCommercial, or CC-BY-NC) provided the original author and source are credited.

\section{INTRODUCTION}

Acharya Susruta has described urdhvajatrugata roga elaborately which deals with the causes, diagnosis and curative procedures of the diseases pertaining to the body above the clavicles, i.e., ear, eye, mouth, nose. Acharya Susruta has described gross ocular anatomy in first chapter of uttara-tantra. In this article we intended to identify the anatomical considerations of the eye are described in many topics like Netra utpatti (embryology development of the eye), Netra -sharir (anatomical considerations of the eye), Panchbhautika concept of embryogenesis of the eye, Measurements and appearance of the eyeball, Sources of origin of its constituents the eyeball, Colors of eye and Effect of Tejo dhatu on eye, Mandala, Sandhi (junctional area), Patala (layer of eyeball), concept of Dristi and Akshi Bandhana (contents of orbit that binds the eyeball). So, there is a need of proper understanding the anatomy in modern prospective. It cannot be characterized by a single entity at all the time because Ayurveda is the science based on the concept of structure and functional understanding. For this study, the basic materials have been collected from the Ayurvedic classics with the available commentaries, as well as text books of modern science have been referred for better understanding of the concept and its comparison with modern science.

\section{Field of Vision}

According to Astang-Hridaya Samhita the eyes of kaphaj prakriti people are red at the angle, unctuous, wide, long with well-designed white and black spheres (sclera and cornea) with more eyelashes. Acharya Susruta has mentioned the eyes of kaphaj prakriti people are red at the angle, white eyes. In the classical text of Ayurveda it has been mentioned there are different types of eyes based on the dominance of dosha in the prakriti like small eye, big eye, round eye, elongated eye, sunken eye, rough eye, steady gaze eye, unsteady gaze eye, normal and healthy eye and these are the factors which can influence the field of vision.

The field of vision is the visual area seen by an eye at a given instant [1]. Visual field testing is a common procedure in almost every eye practice. The visual field is a three-dimensional area of a subject's surroundings that can be seen at any one time around an object of fixation. The visual field can be divided into 
central and peripheral field. The extent of normal visual field with a $5 \mathrm{~mm}$ white color object is superiorly $50^{\circ}$, nasally $60^{\circ}$, inferiorly $70^{\circ}$, and temporally $90^{\circ}$. The field for blue and yellow is roughly $10^{\circ}$ less and that for red and green color is about $20^{\circ}$ less than that for white. The part of the external world visible to one eye when a person fixes his gaze on one point is called the field of vision for that eye. To diagnose blindness in specific portions of the retina, one charts the field of vision for each eye with an instrument called Lister perimetry. The process of charting the monocular field of vision is called Perimetry. It is employed for the diagnosis of various lesions of the visual pathways [2]. All visual fields are designed to measure the entire peripheral vision. In fact, most commonly ordered visual fields only test the central portion of a patient's field of vision. The amount of the field tested depends on which test you perform.

\section{NETRA UTPATTI (Embryology Development of the Eye)}

In the foetus, the parts originated from akasha mahabhuta are- sound, auditory sensation, lightness, fineness and space; the parts from vayu mahabhuta are - tangibility, sense of touch, roughness, impulsion, structuring of body tissues and maintaining of movements of the body and dosha; the parts belonging to agni mahabhuta are visible form, vision, brightness, digestion and heat; those belonging to apa mahabhuta are taste, sense of taste, coldness, softness, unctuousness and moisture; those belonging to prithvi mahabhuta are odour, sensation of smell, heaviness, steadiness and material form[3].

Acharya Sushruta has explained the subtle form of all the Indriyas is present during the formation of Garbha. Eleven indriyas are originated from the vaikarika ahamkara with all its qualities with the help of taijas ahamkara. These eleven indriyas are as follows: ear, skin, eye, tongue, nose, speech organ, hand, sex organ, rectum, feet and mind. The former five are the organ of perception the next five are effector organ and the mind are common to both. The five tanmatras are created out of bhootadi ahamkara with all its qualities with the help of tejas ahamkara. These tanmatras are as follows; sabda, sparsh, rupa, ras and gandha tanmatra. These tanmatra possess special qualities of sound, touch, vision, taste and odour. From these tanmatras the bhutas like akash, vayu, agni, jal and prithvi respectively are originated. Netras are agni predominant sense organ [4]. All the indriyas become unambiguous during the third month. Charaka and Kashyap has opined the same that the genesis of all sense organs including eyes and organogenesis occurs in third month of intrauterine life. According to Janaka of Videha, sense organs existence the seat of senses is first formed. After discussion with the various expert of Ayurveda on the topic of formation of embryo, detailing the manner in which the foetus is formed in the uterus of the mother and the mode of manifestation of its various organs Punarvasu Atreya concluded that all the sense organs are developed simultaneously [5]. Both Charaka and Sushruta consider Indriyas as Atmaja bhava. The clearness of senses (Indriya prasada) is attributing of Satmyaja bhava.

Acharyas Vagbhata opined Indriyas are developed from the essence part of kapha, raktavaha srotas and mahabhutas, after the digestion of its own agni. Vagbhata explained in detail about the embryological development of each part of the eye, Shukla Mandala is developed from the essence of Kapha and it is Pitraja Bhava, Krishna Mandala developed from Rakta and it is Matraja Bhava. Dristhti Mandala is developed from both kapha and rakta and it has both pitrija and matrija bhavas [6].

Panchbhautika Concept of Embryogenesis of the Eye: The anatomy of the eye is described on the basis of panchabhautika composition like, netrabudbuda (eyeball), pala (muscles of eye) are made of prathivi, rakta (blood) is made of agni, krashna (black portion or cornea) is made of vayu, sita (white portion or sclera) is made of jala, asrumarga (channels of tears or lacrimal ducts) is made of akasha mahabhutas [7].

\section{NETRA -SHARIR (Anatomical Considerations of the Eye)}

Acharya Sushruta first ever has described the anatomy of eye in relation to their shape, size of various anatomical components. Sushruta has explained seventy-six different kind of eye diseases and their treatment in uttara tantra of Sushruta Samhita in $2^{\text {nd }}$ AD.

Situation: Shira (head) is chief among all organs. It is the region of the body where vital centres and all senses (indriya) of a living-being are located. Acharyas have considered it is the principal organ among all organs and organelles. Two eye orbits are positioned in the head, which accommodate two Netras, one Chakshurindriya. Two ocular openings are present over the head among the nine external openings of the body which communicate with the external world.

Shape: Acharya Sushruta has described the shape and dimension of Nayana Budbudam (eye ball) as Suvrittam and Gostanakaram. Suvrittam means spherical from all sides. Gostanakaram means shaped like that teat of the cow (oval shape).

Measurements of Eyeball- Acharya Sushruta has given the term Nayana budbuda for eye ball. Sushruta has explained the dimension of eyeball in terms of angula and one angula is equivalent to the central part of the patient's own thumb. Two angula is the antero-posterior diameter of the eyeball. Vertical and horizontal diameter is two and half angula. Shape of the eyeball resembles with the teat of a cow and 
arising from all the bhutas (akasha, vayu, agni, jala, prathivi) with their attributes. In modern perspective, dimension of an adult eyeball is as followsanteroposterior diameter $24 \mathrm{~mm}$, horizontal diameter $23.5 \mathrm{~mm}$, vertical diameter $23 \mathrm{~mm}$, circumference $75 \mathrm{~mm}$, volume $6.5 \mathrm{ml}$ and weight $7 \mathrm{gm} \mathrm{[8].}$

Colors of Eye and Effect of Tejo Dhatu on Eye- In fetal life, tejo dhatu is responsible for vision if tejo dhatu doesn't reach the drashti bhag (visual apparatus), the child is congenitally blind (amblyopia). Color of the eye is depending, whether, tejo dhatu combines with rakta, pitta, kapha or vayu. When tejo dhatu goes to the visual apparatus with the rakta, the child would have raktaksha (red eyes); if it goes with pitta, then pingaksha (yellow eyes); if with kapha then shuklaksha (white eyes); and if with vata then the eyes would be vikrutaksha (deformed eye)[9].

In Upanishada period, ocular anatomy was depicted in philosophical manner. In Brihad Aranyaka Upanishada different structures of eyeball were said to be evolved from different Gods as follows.

Table-3: Shows different structures of eyeball evolved from different goddesses [10].

\begin{tabular}{|l|l|l|l|}
\hline S.No. & God Name & Part of Netra & Part of eyeball \\
\hline 1. & Rudra & Reddish part of eye ball & Blood vessels \\
\hline 2. & Parajanya & Liquid portion & Aqueous \& Vitreous humour \\
\hline 3. & Aditya & Kaninika, Ashrumarga & Lacrimal apparatus \\
\hline 4. & Agni & Blackish portion & Cornea and iris \\
\hline 5. & Indra & Whitish part & Conjunctiva and sclera \\
\hline 6. & Prithvi & Adho Vartma & Lower eyelid \\
\hline 7. & Akasha & Urdhva Vartma & Upper eyelid \\
\hline
\end{tabular}

\section{Mandala}

Acharya Sushruta has enumerated the anatomical parts of the eye consists of mandals are five in number and sandhi and patala are six in number.

1. Pakshma Mandala: This is the first and outermost mandala of the eye formed by the pakshma or eyelashes. Pakshmani means chakshua achadana romani[11]. Pakshma are situated in lid margins called pakshmashaya or pakshma sadana. Paksma is a form of kesa and considered as upadhatu of majja and mala of asthi. It serves to heighten the protection of the eye from dust and foreign bodies.

2. Vartma Mandala: The Upper and Lower eyelids together form a circular structure in front of the eyeball called as vartma mandala. The eyelids are mobile tissues curtains placed in front of the eyeballs. Vartma Mandala is also known as Aksi Kosha considering its protective function. There are two tarunasthi in the eye lids [12]. It is of elliptical space between the upper and lower eyelids. The eyelids feature a row of eyelashes along the eyelid margin. The two eyelids meet each other at medial and lateral angles (two sandhis as kaninika and apanga). The nimesha-unmesha function (blinking) is controlled by vyana $v a y u[13]$. The moement of the vartma (nimeshaunmesha) is regulated by motor nerves are facial (orbicularis muscle), oculomotor (levator palpebrae superioris muscle) and sympathetic fibers. Sensory nerve supply is derived from branches of trigeminal nerve such as lacrimal, supraorbital and supra ocular nerves for upper lid and infraorbital nerve with infra- trochlear branch for lower lid. Each eyelid consists (from anterior to posterior) of following many layers:

i. The skin
ii. The subcutaneous areolar tissue
iii. The layer of striated muscle
iv. Submuscular areolar tissue
v. Fibrous layer
vi. Layer of non-striated muscle fibres
vii. Conjunctiva

3. Shukla Mandala: This mandala is present exactly inside of the vartam mandala and beyond the krishna mandala. The shukla mandala appears white in color. The shukla mandala can be allied with the scleral part of the external fibrous coat of the eyeball. Sclera forms the posterior five-sixth opaque part of the exterior fibrous tunic of the eyeball. Its entire outer surface is covered by Tenon's capsule. In the anterior part it is also covered by bulbar conjunctiva. Thickness of sclera varies considerably in dissimilar individuals and with the age of the person. It is normally thinner in children than the adults and in females than the males. Sclera is thickest posteriorly $(1 \mathrm{~mm})$ and progressively becomes thin when traced anteriorly. Lamina cribrosa is a sieve-like sclera from which fibres of optic nerve pass. Sclera consists of following three layers:

$\begin{array}{cl}\text { I. } & \text { Episcleral tissue } \\ \text { II. } & \text { Sclera proper } \\ \text { III. } & \text { Lamina fusca }\end{array}$

4. Krishna Mandala: The krishana mandala of eye (cornea) is forms one-third of the transverse extent of the eyeball. In modern perspective, cornea is forms anterior one-sixth of the outer fibrous coat of the eyeball. The krishna mandala can be similar with the cornea; seems as blackish because of the iris. Cornea is a transparent, avascular, watch-glass like structure. The uveal tissue constitutes the 
middle vascular coat of eyeball. From anterior to posterior it can be separated into three parts, namely, iris, ciliary body and choroid. Iris is the anterior most part of uveal tract. Iris is a tenuos circular disc corresponding to the diaphragm of a camera. The definitive color of iris be contingent on the anterior limiting layer. In blue iris this layer is thin and contains few pigment cells. While in brown iris it is thick and compactly pigmented.

The physical basis of eye color is determined by the distribution and content of melanocyte cells in the uveal tract of the eye. The iris consists of several layers: the anterior limiting layer and its underlying stroma are the most important for appearance of the eye color [14]. The two primary physiological functions of the cornea. first, functions of the cornea are to act as a major refracting medium; and Second, functions of the cornea to protect the intraocular contents. The stroma of the iris contains collagenous fiber, pigment cells, sphincter pupillae muscle and dilator pupillae muscle.

5. Drishti Mandala: The drishti mandala can be similar with the pupil and lens. Acharya Susruta has described the diameter of drishti mandala (pupil) of eye is one-seventh and one-ninth part of krashna mandala (cornea) and the distance between right and left drishti mandala (interpupillary) are four fingers[15].

\section{Concept of drishti}

As Timira is one among the Drishti gata roga, it is quite essential to know more about drishti.

Definition of Drasti (area of sight/vision)- The drashti is of the size of a cotyledon of the lentil, composed of the finest parts of panchmahabhutas, gleaming like a glow-worm or a spark, covered by the external coat of the eye and appearing like a hole[16].

The concept of Drishti by Acharya Sushruta is little different and all the description of Drishti given by him points to the pupil i.e.

- Masura dala matra [size of a Masura dala]

- Prasada of Panchamahaboota

- Covered by the external Patala

- Sparkle like glow worm (Khadyotavisfulingabha)

- Constantly irrigated by the cold aqueous

- Shape resembles a hole (Vivirakritim)

- Benefited with cold things

\section{SANDHI (JUNCTIONAL AREAS)}

Sandhi is the "Junctional Areas" between two Mandalas. The Sandhi are 6 in number. They are-

1. Pakshma-Vartma gata Sandhi: The junction of pakshma mandala (eyelashes) and vartma mandala (eyelids) is called as the Pakshma-vartma gata sandhi and it is considered as the lid margin. The lid margin is about 2-mm broad and is divided into two parts by the punctum. The medial, lacrimal portion is rounded and destitute of lashes or glands. The lateral, ciliary portion consists of a rounded anterior border, a sharp posterior border (placed against the globe) and an inter-marginal strip (between the two borders). The grey line (which marks junction of skin and conjunctiva) divides the inter-marginal strip into an anterior strip bearing 23 rows of lashes and a posterior strip on which openings of meibomian glands are settled in a row.

2. Vartma-Shukla gata Sandhi: The junction of vartma mandala (eyelids) and shukla mandala (sclera) is known as Vartma-shukla gata sandhi. It is considered as conjunctiva fornix. Conjunctival fornix conjoins the bulbar conjunctiva with the palpebral conjunctiva. It can be subdivided into superior, inferior, medial and lateral fornixes. The conjunctiva contains Mucin secretory glands like goblet cells, crypts of Henle, glands of manz. These glands secrete mucus which is important for wetting the cornea and conjunctiva. Accessory lacrimal glands like glands of Krause, glands of Wolfring.

3. Shukla - Krishna gata Sandhi: The junction of Shukla mandala (cornea) and Krishna mandala (sclera) is known as Shukla-krishna gata sandhi. This junctional area can be considered as the corneoscleral junction and limbus. A 3-mm ridge of bulbar conjunctiva round the cornea is called limbal conjunctiva. In the area of limbus, the conjunctiva, Tenon's capsule and the episcleral tissue are merged into a dense tissue which is strongly adherent to the underlying corneoscleral junction. At the limbus, the epithelium of conjunctiva becomes continuous with that of cornea.

4. Krishna - Drishti gata Sandhi: The junction of krishna and drishti mandala is known as Krishnadrishti gata Sandhi. This junctional area can be similar with the iris part in krishna mandala, this Sandhi can be explained and the central free margin of the iris, which rests on the anterior capsule of the lens, can be considered as the Krishna-drishti gata Sandhi. The peripheral border or root of the iris attaches to the ciliary body while its central or free margin forms the rim of the pupil.

5. Kaneenika Sandhi: Dalhana describes this Sandhi and it can be taken as the inner or nasal canthus of the eye. The Canthus is either corner of the eye where the upper and lower eyelids adjoin. More specifically, the inner and outer canthus is respectively, the medial and lateral ends of the palpebral fissure. The palpebral fissure is the elliptic space amid the medial and lateral canthi of the two open lids. The inner 
canthus (medial palpebral commissure) is prolonged for a short distance toward the nose, and the two eyelids are divided by a triangular space, the lacus lacrimalis. The inner canthus has two structures-

i. Plica semilunaris-It is a pinkish crescentic fold of conjunctiva, present in the medial canthus. Its lateral free border is concave. It is a vestigial structure in human beings and represents the nictitating membrane.

ii. Caruncle- The caruncle is a small, ovoid, pinkish mass, situated in the inner canthus just medial to the plica semilunaris. In really, it is a piece of modified skin and so is enclosed with stratified squamous epithelium and contains sweat glands, sebaceous glands and hair follicles.

6. Apanga Sandhi: Acharya Dalhana describes Apanga sandhi and it can be considered as the outer canthus of the eye. It is one of the marma points. The outer canthus (lateral palpebral commissure) is more acute than the medial, and the eyelids here lie in close contact with the bulb of the eye.

\section{PATALA (Layers of Eyeball)}

Acharya sushruta has described the patala are most important structure of netra sharir. It can be appeared like as a layer of the eyeball or film or coating over the eyes. The two patala are present in the eyelids and the other four Patala in the internal eye ball. Out of them the first Patala (outermost) subsists in the tejas and jala, second Patala in the mansa (muscle), third Patala in the meda (fat), forth Patala in the asthi. Their thickness of entire patal is equal to one-fifth of pupil. The pathogenesis of Drishtigata roga, has delineate in terms of involvement of successive patala. The prognosis of the disease also depends upon the involvement of respective patala. Acharya Sushruta has considered the different akshi patala and their constituting factors as shown below:

I \& ii. Patala (Two Vartama Patala): The upper and lower eyelids are divided by a horizontal furrow (sulcus) into an orbital and tarsal part.

iii. First Bahya Patala (Tejojalashrita): It is the outermost first patala, supported by tejas \& jala. The outermost patala can be appeared like as the aqueous humour. Acharya Dalhana has described the outermost patala as tejojalashrita. According to Dalhana, the word teja means alochaka pitta and so siragata rakta can be occupied as teja. Jala, according to him implies rasa dhatu of skin. So, it can be considered that the first patala is the ashraya for rasa and rakta dhatus. The aqueous humour is a clear watery fluid filling in the anterior chamber $(0.25 \mathrm{ml})$ and posterior chamber $(0.06 \mathrm{ml})$ of the eyeball.
It plays a significant metabolic role by providing substrates and by removing metabolites from the avascular cornea and lens. The composition of aqueous humour in anterior chamber differs from that of the aqueous humour in posterior chamber because of metabolic interchange. The physiological processes concerned with the dynamics of aqueous humour are its production, drainage and maintenance of intraocular pressure.

iv. SECOND PATALA: The location of second patala is inner side of the bahya patala. It is the seat of pisita (muscles). The second patala can be taken as ciliary body. Both iris and ciliary body are mesodermal in origin and contain muscles tissue. The ciliary muscle is composed of smooth muscle fibres oriented in longitudinal, radial, and circular directions. Interweaving occurs between fibre bundles and from layer to layer, such that various amounts of connective tissue are found among the muscle bundles. The longitudinal muscle fibres (of Brücke) lie adjacent to the supra ciliaris and parallel to the sclera. Each muscle bundle looks like a long narrow $\mathrm{V}$, the base of which is at the scleral spur, whereas the apex is in the choroid.

v. THIRD PATALA: This patala is seat of meda (fat). The third patal can be appeared like as vitreous humour. The Vitreous humour is an inert, transparent, jelly-like structure that fills the posterior four-fifth of the cavity of eyeball and is about $4 \mathrm{ml}$ in volume. It is a hydrophilic gel that primarily serves the optical functions. In addition, it mechanically stabilizes the volume of the globe and is a pathway for nutrients to attain the lens and retina. The vitreous body can be separated into two parts; the cortex and the nucleus (the main vitreous body).

vi. FOURTH PATALA: This patala is seat of asthi (bone). The fourth patal can be appeared like as crystalline lens and retina. The lens is a transparent, biconvex, crystalline structure placed amid iris and the vitreous in a saucer shaped depression the patellar fossa. The Retina, the innermost tunic of the eyeball, is a thin, delicate and transparent membrane. It is the almost highly-developed tissue of the eye. It seems purplish-red due to the visual purple of the rods and underlying vascular choroid.

\section{Structure of the Lens-}

1. Lens capsule

2. Anterior epithelium

3. Lens fibres

4. Suspensory ligaments of lens 
Retina consists of following ten layers (arranged from outward to inward):

1. Pigment epithelium

2. Layer of rods and cones

3. External limiting membrane

4. Outer nuclear layer

5. Outer plexiform layer

6. Inner nuclear layer

7. Inner plexiform layer

8. Ganglion cell layer

9. Nerve fibre layer (stratum opticum) and

10. Internal limiting membrane.

This description can be considered as a misunderstanding from Dalhana. Actually, he had misinterpreted the word abhyantara given by Sushruta in the description of prathama patalagata timira and considered the first patala as the abhyantara (innermost) patala. According to some other scholars, the patala can be taken as the layers of the cornea. There is one other view in which the patala are taken as different layers of the lens itself. To justify this, they say that the lens is the only structure where the changes of the disease timira, kacha and linganasha are taking place. They assume the anterior lens capsule as the first patala and nucleus as the fourth patala.

According to some other views, the patala can be taken as different layers of retina. There is third patala participation for the diseases pittavidagdha drishti and kaphavidagdha drishti. These are the diseases where patients complain of day blindness and night blindness respectively. As these diseases occur due to degeneration of rods and cones. The Patala can be taken as different layers of retina. But, by taking the retina as patala, we cannot explain the clinical entity timira. However, there is another view that, all these patala are seated in dristi mandala. Their thickness is one fifth of dristi mandala. This will lead to concept of dividing dristi mandala in to four distinct layers; each layers of retina representing patala.

\section{Contents of Orbit That Binds the Eye Ball (Akshi Bandhana)-}

The both eyeballs are held in position by the inherent properties of the sira (veins, arteries and nerves), kandara (tendons and ligaments), meda (orbital fat), Kalkaasthi (fascia that is attached to the bony cavity) and Sleshma bandana (especially the eye ball is supported by the orbital fat) kapha as well as by the lining mucous membrane along with its vessels next to the cartilage. The vessels, ligaments, bones and joints if the living beings have strength because they are covered by the muscles [17].

According to Sasilekha commentary of Acharya Indu, the first patala consists of sira guna, the qualities of teja and jala are also seen here. The second Patala has kandara guna which is derivative of mamsa dhatu. The third Patala has meda guna; exact visual perception takes place in this patala as dristi is seated in medas, kalakasthi remains outside meda.

Extra Ocular Muscles of the Eyes: The muscles of the globe can be divided into two groups: the involuntary intrinsic muscles and the voluntary extrinsic muscles. The intrinsic muscles- the ciliary muscle, the iris sphincter, and the iris dilator are located inside the eye; these muscles control the movement of internal ocular structures. The extrinsic muscles are six extraocular muscles; it is attached to the sclera and control movement of the globe. The Rectus muscles are superior, inferior, medial and lateral. The oblique muscles include superior and inferior. The extraocular muscles rotate the eyeball round vertical, horizontal and antero-posterior axes. Medial and lateral rectus muscles are virtually parallel to the optical axis of the eyeball, so, they have got only the main action. While superior and inferior rectus muscles make an angle of $23^{\circ}$ and reflected tendons of the superior and inferior oblique muscles of $51^{\circ}$ with the optical axis in the primary position, so, they have subsidiary actions in addition to the main action.

\section{Sira (Veins, Arteries and Nerves)-}

Acharya Dalhana describes sira are plural word and it means can be considered as the orbit has a single ophthalmic artery but two ophthalmic veins.

Sira (Veins): Acharya Susruta has descried both the eye have 38 siras[18]. Among them vata is carried in eight sira, pitta, rakta and kapha are carried in ten sira each. Acharya vagbhatta has explained total number of 56 siras present in the both eyes. Among them two siras each are responsible for lid movement (nimesha-unmesha) and these six siras should not be opened during sira vyadha. The superior and inferior ophthalmic veins primarily drain into the cavernous sinus. On its course the superior and inferior ophthalmic veins give off several side branches: central retinal vein, anterior and posterior ethmoid veins, lacrimal vein, superior and inferior vortex veins, anterior ciliary veins, supraorbital and infraorbital vein, superior, inferior, lateral and medial muscular veins branches.

Dhamani (Arteries): The two dhamanies helps in visual perception, two for the flow of tears [19]. The ophthalmic artery is a branch of the internal carotid artery that supplies all structure in the orbit. The ophthalmic artery orginate in the cavernous sinus, enters the orbit via the optic canal, then turns medially and continues along the medial wall of the orbit, dividing at the medial end of the upper eyelid into terminal branches- supratrochlear artery and dorsal nasal branches. On its course the ophthalmic artery gives off several side branches: central retinal artery, lacrimal artery, ciliary arteries, supraorbital artery, anterior and posterior ethmoidal arteries, meningeal branch, medial palpebral arteries and muscular branches. There are 
rupa vaha dhamani to transmit visual perception and asruvaha dhamani for the flow of tears one in each eye.

Cranial Nerve Innervation of Ocular StructureThe orbital structures are innervated by cranial nerves optic nerve (II), oculomotor nerve (III), trochlear nerve (IV), trigeminal nerve (V), abducens nerve (VI), and facial nerve (VII). The Motor functions of the striated muscles are controlled by oculomotor nerve, trochlear nerve, abducens nerve and facial nerve. The trigeminal nerve transmits the sensory supply from the orbital structures. The optic nerve carries visual information.

Kandara (tendons and ligaments) of the Eyeball: The kandara can be considered as trochlea of superior oblique and suspensory ligament of eyeball. The trochlea of superior oblique is a pulley alike structure in the eye. The tendon of the trochlea of superior oblique passes through, it is situated on the superior nasal aspect of the frontal bone, it is the only cartilage found in the normal orbit. The suspensory ligament of eyeball (Lockwood's ligament) forms a hammock stretching below the eyeball between the medial and lateral check ligaments and enwrapping the inferior rectus and inferior oblique muscles of the eye.

Snyau, Peshi: There is a snayu of prithu type in the eyes. Two peshi are situated in both eyes and which circular (Mandala) in shape.

Meda and Sleshma Bandana (Orbital fat) of the Eyeball: The Meda and Sleshma Bandana can be considered as Orbital fat of both eyelids. The Orbital fat lies posterior to the orbital septum and anterior to the levator aponeurosis (upper eyelid) or the capsulepalpebral fascia (lower eyelid). In the upper eyelid, there are two fat pouches: nasal and central. In the lower eyelid, there are three fat pockets: nasal, central, and temporal. These pockets are surrounded by thin fibrous sheaths that are forward continuations of the anterior orbito-septal system.

Kalkaasthi of the Eyeball: The Kalkaasthi can be considered as tenon capsule. The Tenon capsule also known as the fascial sheath of the eyeball (fascia bulbi), it is a thin membrane which envelops the eyeball from the optic nerve to the corneal limbus, separating it from the orbital fat and forming a socket in which it moves. The inner surface of the Tenon capsule is smooth and is separated from the outer surface of the sclera by the peri-scleral lymph space.

Marma (Vulnerable Area): There are three marma related to eye i.e. Apanga, Aavarta and Shringataka. The two apanga marma are situated on the outer side of the orbit, below the lateral end the of the eye-brows. The injury of apanga and avarta marma to them cause blindness or diminished vision. The apanga marma and avarta marma is a type of shira marma and half angula in size. The Avarta marma is above the end of the eyebrows. The Sringataka marma are the merging of vessels providing nutrition to sense organs like nose, ear, eye and tongue. It is type of sira marma and four angula in size and injury to this also results in immediate death.

\begin{tabular}{|l|l|}
\hline Structure or Entities as per Ayurvedic text & Correlation of Structure or Entities as per Modern text \\
\hline Pakshma mandala & Eyelashes. \\
\hline Vartma mandala & Upper and Lower eyelids. \\
\hline Shukla mandala & Sacral part of the external fibrous coat of eyeball. \\
\hline Krishna mandala & Cornea and iris. \\
\hline Drishti mandala & Pupil and lens. \\
\hline Pakshma-Vartma gata Sandhi & Lid margins of eyelashes \\
\hline Vartma-Shukla gata Sandhi & conjunctiva fornix \\
\hline Shukla- Krishna gata Sandhi & Corneoscleral junction and limbus. \\
\hline Krishna - Drishti gata Sandhi & central free margin of the iris, the anterior capsule of the lens. \\
\hline Kaneenika Sandhi & Inner canthus of the eye, Plica semilunaris and caruncle. \\
\hline Apanga Sandhi & outer canthus of the eye. \\
\hline Two Vartama Patala & Orbital and tarsal part of the eyelids. \\
\hline Tejojala-ashrita Patala & Aqueous humour \\
\hline Mamsa-ashrita Patala & Ciliary body, choroid \\
\hline Medoa-ashrita Patala & Vitreous humour \\
\hline Asthi-ashrita Patala & Crystalline lens and retina \\
\hline
\end{tabular}

\section{DISCUSSION}

In this literary study we collected various data from the Ayurvedic classics with the available commentaries, as well as text books of modern medical sciences, various articles for better understanding of the netra sharir and its comparison with contemporary science. Acharyas have explained prakriti also influences eyes in terms of size, shape of eyes, appearance of eyes, dryness or roughness of eyes, color of eyes, lashes of eyes, movement of eyes and some specific features of eye. These relates to the constitutional variations of the individuals. Acharya Sushruta has described "Sarvendriyaanam Nayanampradhanam[20]”. Acharya Sushruta first ever 
has described the anatomy of eye in relation to their shape, size of various anatomical components. Sushruta has explained seventy-six different kinds of eye diseases and their treatment in uttara tantra. The Netra execute both physiological functions roopagrahana and buddhigrahana as it is the seat of Alochaka pitta. It is predominant of tejo mahabhuta so, there is always dread of kapha to eye.

The shape of netra is like suvrittam means spherical from all sides and gostanakara means shaped like that teat of the cow (oval shape). Acharya Sushruta described the anatomical parts of the eye consists of mandals are five in number and sandhi and patala are six in number [21]. Sandhi is the "Junctional Areas" between two Mandalas. The Sandhi are 6 in number. Acharya sushruta has described the patala are most important structure of netra sharir. The first patala is the seat of tejas and jala and it can be taken as cornea and aqueous humour; the second patala is the seat of mamsa and it can be taken as iris and ciliary body. The third patala is the seat of medo and it can be taken as vitreous humour, it is a jelly like structure which resembles medas. The fourth patala is the seat of asthi and it can be taken as lens and retina, as it is the seat for linganasha.

These are the parts where doshas get localized and produce various types of netra rogas. When doshas invade gradually deeper in the patala it causes timira, Kacha and Linganasa. Netra also consists of Akshi bandhana, sira, pesi, dhamani, marma, snayu and other accessory parts. Thus, whole of patala Mandala, Sandhi, Akshi bandhana, sira, pesi, dhamani, marma, snayu completes the netra sharira.

To conclude, we can say that Patala were described by Ancient Acharyas in order to show the severity of the diseases when they involve deeper tissues and no single structure can be correlated with specific Patala accurately. Patala can be taken as different structures in different contexts.

\section{REFEARANCE}

1. Hall, J.E., \& Guyton, A.C. (2010). Visual Pathway and Central Processing. In Anura K (Eds.), Guyton \& Hall Textbook of Medical. India: Elsevier Health Sciences; 779-790

2. Ghai, C.L. (2013). Perimetry (charting the field of vision). In Ghai C.L.(Eds.), A Textbook of Practical Physiology. Jaypee Brothers Medical Publishers(P) Ltd; 200-204

3. Chakrapanidatta. Sharir Sthana, Mahatigarbhavakranti Shariradhyaya. In: Kushwaha H.C. (Eds.), Ayurveda deepika on Charaka Samhita: Revised edition.. Varanasi, India: Chaukambha Orientalia; 2009; 788-813.

4. Sushrut. Sharir Sthana, Sarvabhuta-chinta Shariradhyaya. In: Shastri A.D. (Eds.), Ayurved Tatvasandipika on Susruta Samhita: Revised edition. (pp.). Varanasi, India: Chaukhamba Sanskrit Sansthan; 1-10.

5. Chakrapanidatta. (2009). Sharir Sthana, Sharira Vichaya Sharira adhyaya. In: Kushwaha HC (Eds.), Ayurveda deepika on Charaka Samhita: Revised edition. Varanasi, India: Chaukambha Orientalia, 824-844

6. Vaghbhatta. (2016). Sharir Sthana, Angavibhaga Sharir Adhyaya. In: Gupta AD, (Eds.), Astanga Sangraha. Revised edition. Varanasi, India: Chaukambha Krishnadas Academy, 297-308

7. Sushrut. (2016). Uttara tantram, Aupadravikah adhyaya. In: Shastri A.D. (Eds.), Ayurved Tatvasandipika on Susruta Samhita: Revised edition. Varanasi, India: Chaukhamba Sanskrit Sansthan, 1-17

8. Khurana AK. (Aug 31. 2015). Anatomy and development of the eye. In: Khurana AK. \& Khurana B. (Eds.), Comprehensive Ophthalmology with Supplementary Book Review of Ophthalmology. $5^{\text {th }}$ edition. New Delhi, India: New Age International (P) Limited, Publishers, 1-11

9. Sushrut. Sharir Sthana, Sukrasonitasuddhi Shariradhyaya. In: Shastri A.D. (Eds.), Ayurved Tatvasandipika on Susruta Samhita: Revised edition. Varanasi, India: Chaukhamba Sanskrit Sansthan; 11-36.

10. Madhukar, L., \& Nivrutti, B. (2018). An Imperative Review Study on Concept of Ophthalmology in Ayurveda in the Purview of Rachana Sharir (Human Anatomy). World Journal of Pharmaceutical Research, 7(08), 140-151.

11. Dalhan. (2009). Sutra Sthana, Chayavipratipatti adhyaya. In: Trikam Y. (Eds.), Nibandha Sangraha on Sushrut Samhita. Revised edition. Varanasi, India: Chaukhamba Sanskrit Sansthan; 139-148

12. Dalhan. (2009). Sharir Sthana, Dhamanivyakarana Shariradhyaya. In: Trikam Y, (Eds.), Nibandha Sangraha on Sushrut Samhita. Revised edition. Varanasi, India: Chaukhamba Sanskrit Sansthan, 363-369

13. Mohrana, P., \& Roushan, R. (2018). A Critical Review Of Vyana Vayu In Modern Physiological Perspective. International journal of basic and applied research, 8(11), 75-82.

14. Boissy, \& R.E. (1998). Extracutaneous Melanocytes. In the pigmentary system physiology and pathophysiology (Nordlund, J.J. eds), 59-72, Oxford university Press.

15. Sushrut. (2016). Sutra Sthana, Aturopakramaniyah adhyaya. In: Shastri A.D. (Eds.), Ayurved Tatvasandipika on Susruta Samhita: Revised edition. Varanasi, India: Chaukhamba Sanskrit Sansthan; 167-177

16. Sushrut. (2016). Uttara tantram, Dristigataroga vijnaniyah adhyaya. In: Shastri A.D. (Eds.), Ayurved Tatvasandipika on Susruta Samhita: Revised edition. Varanasi, India: Chaukhamba Sanskrit Sansthan, 40-48 
17. Sushrut. (2016). Sharir Sthana, Sarirasankhyavyakarana Shariradhyaya. In: Shastri A.D. (Eds.), Ayurved Tatvasandipika on Susruta Samhita: Revised edition. Varanasi, India: Chaukhamba Sanskrit Sansthan; 54-67

18. Dalhan. (2009). Sharir Sthana, Siravarnavibhakti Shariradhyaya. In: Trikam Y, (Eds.), Nibandha Sangraha on Sushrut Samhita. Revised edition. Varanasi, India: Chaukhamba Sanskrit Sansthan; 376-379
19. Dalhan. (2009). Sharir Sthana, Dhamanivyakarana Shariradhyaya. In: Trikam Y, (Eds.), Nibandha Sangraha on Sushrut Samhita. Revised edition. Varanasi, India: Chaukhamba Sanskrit Sansthan; 383-387

20. Dalhan. (2009). Sutra Sthana, Vedotaptti Adhyaya. In: Trikam Y, (Eds.), Nibandha Sangraha on Sushrut Samhita. Revised edition. Varanasi, India: Chaukhamba Sanskrit Sansthan; 1-10. 